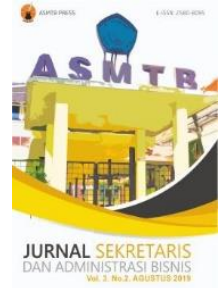

\title{
ANALYSIS PERCEIVE VALUE, BRAND PACKAGING, AND BRAND TRUST OF PURCHASE INTENTION IN SHOPEE MARKETPLACE, MODERATED BY GENDER DIFFERENCES
}

Laksmi Saraswati Hadiansyah ${ }^{1}$, Marheni Eka Saputri ${ }^{2}$

${ }_{1,2}$ Business Administration, Faculty of Communication and Business, Telkom Universisty

${ }^{1}$ laksmisaras@ student.telkomuniversity.ac.id; ${ }^{2}$ marhenieka@ @elkomuniversity.ac.id

\begin{tabular}{l}
\hline Article info \\
\hline Article history: \\
Received $29^{\text {th }}$ February 2020 \\
Received in revised form $03^{\text {rd }}$ March \\
2020 \\
Accepted $08^{\text {th }}$ October 2020 \\
\hline Keywords: \\
Perceived Value, \\
Brand Packaging, \\
Brand Trust, \\
Gender, \\
Purchase Intention
\end{tabular}

\section{Abstract}

Society has determined the traits that are masculine and feminine, which might affect their decision making and purchase intention. Understanding the difference between male and female regarding their purchase intention and behavior is growing. Accordingly, this paper outlines three main factors that may affect male and female purchase intention (perceived value - brand packaging - brand trust). The criteria of the population in this study are consumers of Shopee. The sampling technique used purposive sampling and the method of collecting data through online questionnaires to 100 respondents who were in accordance with the criteria of the population. Structural Equation Modeling (SEM) was used to test the hypotheses. Based on the Descriptive Analysis results, Perceived value is in "good" category with percentage value $79 \%$, brand packaging is in "good" category with percentage value $76 \%$, and brand trust is in "good" category with percentage value $76 \%$. All the main factors (perceived value brand packaging- brand trust) are have a significant effect to purchase intention, meanwhile the differences of gender (male and female) doesn't show a moderating effect to purchase intention. So there are a same perception of purchase intention between male and female customer. 


\section{BACKGROUND}

Internet user in the world, especially in developing country such as Indonesia increase rapidly. This phenomenon effect e-commerce growth in Indonesia also encourage competition between marketplace in Indonesia. Shopee is the leading online shopping platform in Southeast Asia that offers convenient and seamless shopping their users. In Indonesia, Shopee application has been downloaded more than 74 million times through the Google Play Store or App Store (Setyowati, 2018). Moreover in Indonesia itself, online shopping identical with woman behavior, meanwhile the product that sold in marketplace such as Shopee are universal product than can be used by men and female. On the research conducted by MarkPlus Inc show that Shopee ranked as number one top of mind with a percentage of $56 \%$ as an e-commerce brand that first appeared in the minds of women, followed by Tokopedia with 16.3\%, Bukalapak 6,4\%, JD.ID 2,4\%, Blibli.com 1,9\% and Zalora 1,2\%. This research take a sample 1200 respondent from Jawa, Sumatera, Kalimantan, and Bali. (Source: Rhesa Dwi Prabowo, Head of communication, Hi-Tech and Media Industry MarkPlus, Inc.)

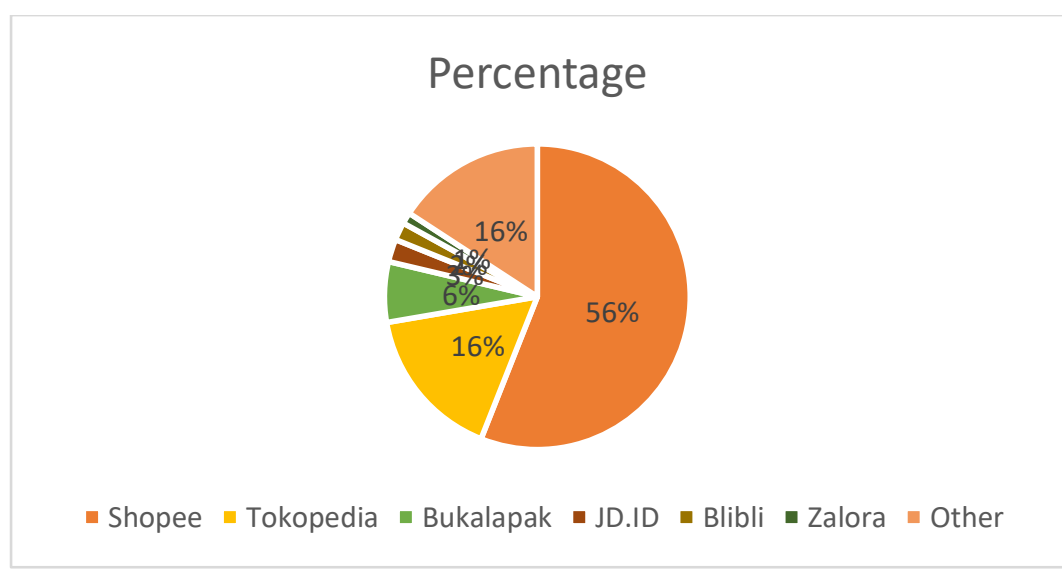

Figure 1.2 Percentage Woman's Top of Mind

Source: Author Data Processing; Markplus Inc.

Regarding to gender phenomenon mindset issue, Shopee try to reach men customer by create a marketing promotion campaign and change the mindset of online shopping identical with woman. On early 2019 Shopee launched a program called Shopee Men Sale 22.2, this event held on 1 February 2019 until 22 February 2019. Shopee Men sale is a special event that give a special price and promotion during the event held.

Launching those programs also encourage a good perception of Shopee form the customer. A good perception value will influence customer purchase intention to the product. This is consistent with research conducted by Muhammad Fajar Jayadi (2018) that perceived value influences simultaneously into customer purchase intention.

By those program above, we could see that Shopee wants to build a good perceived value especially for emotional value to customer and price value of their product. 
Shopee has indeed targeted women as its main target market. This can be seen from the company logo in the form of an orange tote bag. More than that the website design and mobile application design also show a similar form of design such as dominated with orange color. The design of website gives important role in marketing due to its major contribution to introducing the product to the market. Besides having a promotional program called mensale, Shopee also change their visual color from orange into blue product packaging.

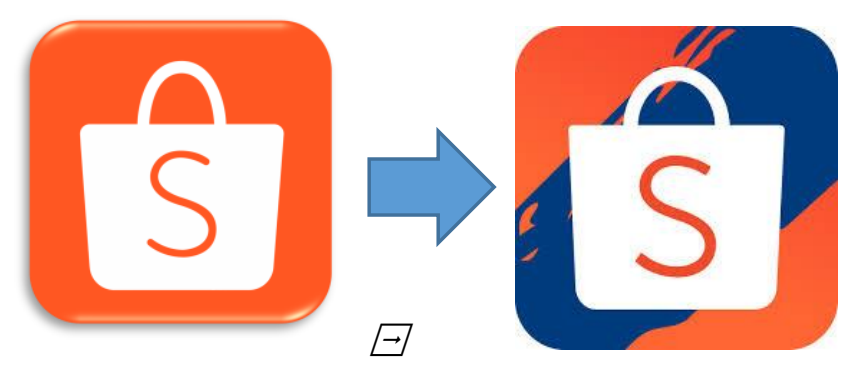

Figure 1.5 Shopee Logo Transformation

Source: $\underline{w w w . s h o p e e . c o . i d}$

Another factors that influencing customer purchase intention is customer trust in a brand (brand trust) is defined as the customer's desire to rely on a brand with the risks faced because expectations of the brand will lead to positive results (Lau \& Lee, 1999, p. 344) on Adrian Junio Adiwidjaja 2017. So to keep a positive expectation and gain the trust from the customer, Shopee make some innovative program and gained trust from the customer by star seller program.

Shopee make a mensale program and also modify their packaging which they want to show to their customer such as website display, mobile app display, and logo. Within the research the researcher wants to find out how customer purchase intention influences by three main factors (perceived value, product package and brand trust) moderating with gender differences. Based on the background described above, the author interested to do the research of "Analysis Perceived Value, Brand Packaging, Brand Trust of Purchase Intention in Shopee Marketplace, Moderated by Gender Differences".

\subsection{Research Objectives}

According to the data above, the research aims to investigate

a. To know how Perceived value influence Purchase Intention on Shopee

b. To know how Product packaging influence Purchase Intention on Shopee

c. To know how Brand trust influences Purchase Intention on Shopee

d. To know how the relationship between Perceived value and Purchase Intention compare female customer and male customer.

e. To know how the relationship between Product packaging and Purchase Intention compare female customer and male customer.

f. To know how the relationship between Brand trust and Purchase Intention compare female customer and male customer. 


\section{LITERATURE REVIEW}

\subsubsection{Perceived Value}

Perceived value which is defined as "the consumer's overall assessment of the utility of a product (or service) based on perceptions of what is received and what is given". Within this definition, Zeithaml (1988) on Mohd Nazri Abdul (2016). According to Arifin et al, 2013 on Heru Triatmaja Eryadi (2016) Perceived Value is an overall consumer assessment of the benefits of a product based on perceptions about what they have received and what they have provided. The perceived value itself is constructed by four indicators, as well as:

a. Emotional value is the value associated with consumer emotions

b. Social value is related to consumers' perceptions of products, judged in terms of social value.

c. Price is related to consumer perceptions of product prices seen from their ability economically.

d. Quality is related to product quality according to consumers' perceptions by their experience and ability to compare with other products.

\subsubsection{Brand Package}

According to the publication "Private Label Buyer," studies show that packaging of products can increase visibility and set one product apart from their competitors. Increased competition and clutter on retail store means that package must now perform many sales task - from attaching attention to describing the product. Kotler (2012:256).

\subsubsection{Brand Trust}

According to Christine R (2018) Trust is one major factor that makes a big influence on the repurchase intention. Therefore, a given trust must be used well and do not make the customers get angry or disappointed because of the seller's attitude itself. Another source from Oxford Dictionaries, defines trust can be defined as "the belief that somebody/something is good, sincere, honest, etc. and will not try to harm or trick you."

\subsubsection{Gender Perception}

Society has determined the traits that are masculine and feminine, and the extent to which an individual identifies with these attributed traits is his or her gender identity (Stets and Burke, 1999 on Jinhee Jun, 2012). Previous studies showed the gender differences in making online purchases. (Sohaib and Kang, 2018)

\subsubsection{Purchase Intention}

Kotler and Armstrong (2012: 154) say that purchase intention is "In the evaluation stage, the consumer form and intention to buy the most preferred brand". While Simamora (2001: 106), said that "purchase intention of a product arises because of the basis of trust in the desired product with the ability to buy products". 
The indicators of consumer purchase intention according to Schiffman and Kanuk (2008: 227) is as follows:

1. Interest in seeking more information about product.

2. Consider to buy the product.

3. The desire to know the product.

4. Interest in trying products.

5. The desire to have a product.

\subsection{Research Framework}

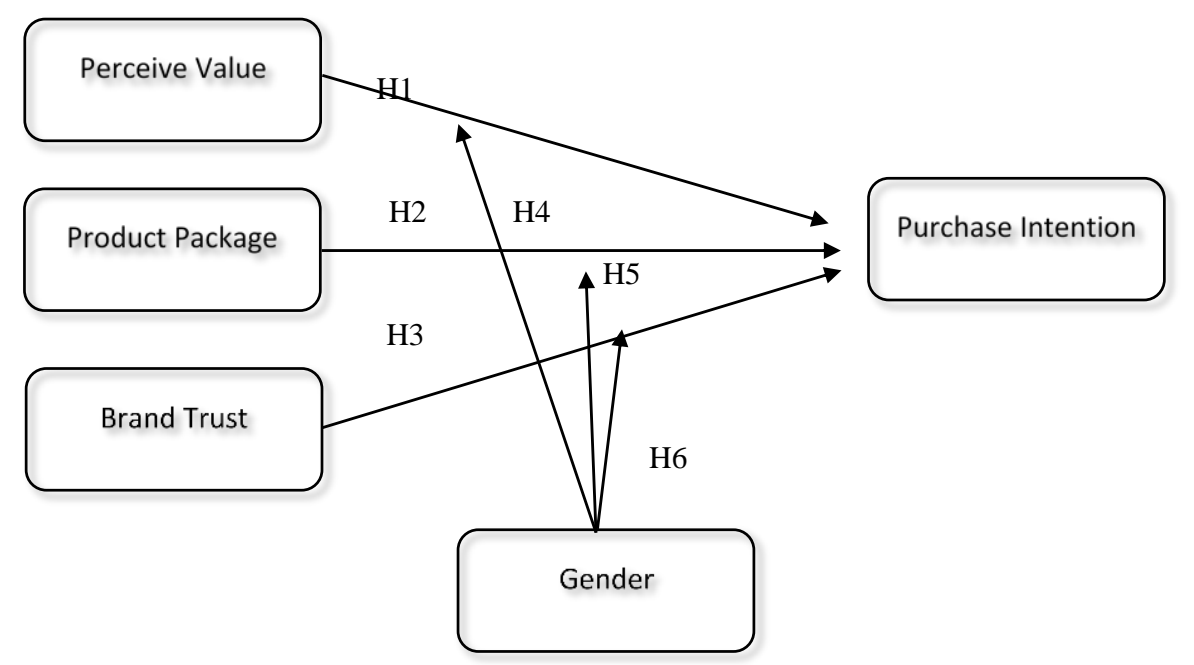

\section{RESEARCH METHOD}

\subsection{Types of Research}

Type of this research is a type of descriptive research that used to analyze data by describing data that has been collected. The research method is determined on the basis of theories that support the problem-solving process and to provide explanations and descriptions to deal with the phenomena that occur.

\subsection{Population and Sample}

Population is a generalization area consisting of objects / subjects that have certain qualities and characteristics set by researchers to be studied and then conclusions drawn (Sugiyono, 2014:80). The population in this study were consumers who had purchase at Shopee Indonesia whose numbers are not known with certainty.

According to Sugiyono (2014:140), the sample is part of the number and characteristics possessed by the population which are considered to represent the entire population. In this study, the population is unknown. Determination of the number of samples in this study using the Bernoulli formula. 


\subsection{Data Analysis Technique}

Data Analysis of this study is using scientific method because it has fulfilled scientific principles that are concrete, empirical, objective, measurable, rational and systematic. In this study, the method of data collection uses two ways, which are: primary data, using questionnaire method, there are several written statements that will be answered by the respondent in accordance with the available alternative answers. And secondary data obtained by using library research conducted by studying and researching the literature in the form of previous studies, books, website, articles relevant to the problems in this study

\section{RESEARCH RESULTS AND DISCUSSION}

\subsection{Validity and Reliability}

Following the guidelines of Fornell and Larcker (1981), the results pointed that all of the square roots of AVEs are greater than the inter-construct correlations. Discriminant validity can be achieved when the AVE value is greater than 0.5 .

\begin{tabular}{|l|l|}
\hline \multicolumn{1}{|c|}{ Variable } & \multicolumn{1}{c|}{ AVE } \\
\hline $\mathrm{X} 1$ & 0.528 \\
\hline $\mathrm{X} 2$ & 0.602 \\
\hline $\mathrm{X} 3$ & 0.698 \\
\hline $\mathrm{Y}$ & 0.696 \\
\hline
\end{tabular}

\subsection{Descriptive Analysis}

1) Descriptive Analysis of Perceived Value

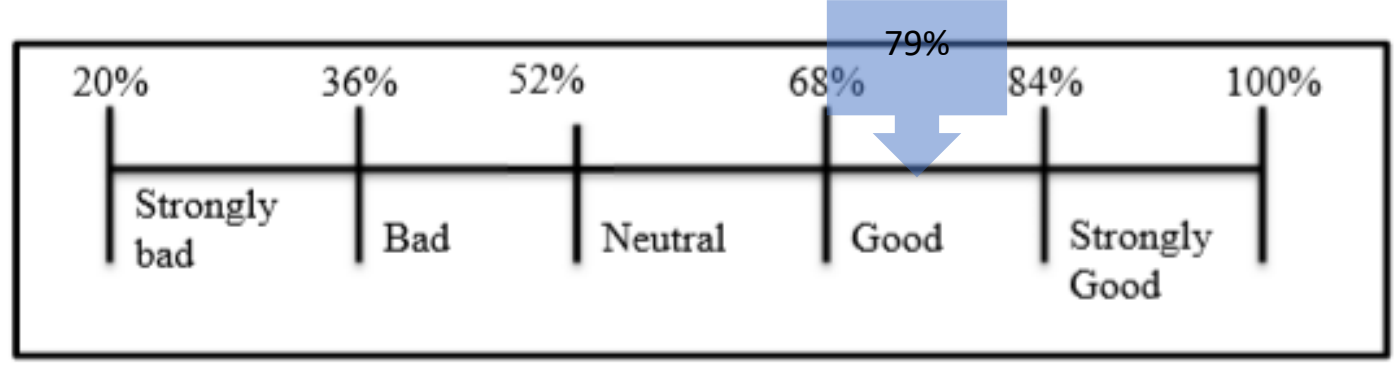

Figure 4.5 Continuum Line Perceived Value

Source: Data that has been Processed, 2019

Based on the figure above Perceived value is in "good" category with percentage value $79 \%$ on continuum line. Therefore, we can assume that respondent perception to perceived value is good. Perceived Value has the value tcount (3.507) > ttable (1.984) and the level of significance $0.000<$ 0.05 , it can be concluded that partially there is a significant effect of Perceived Value on Purchase Intention. 
2) Descriptive Analysis of Brand Packaging

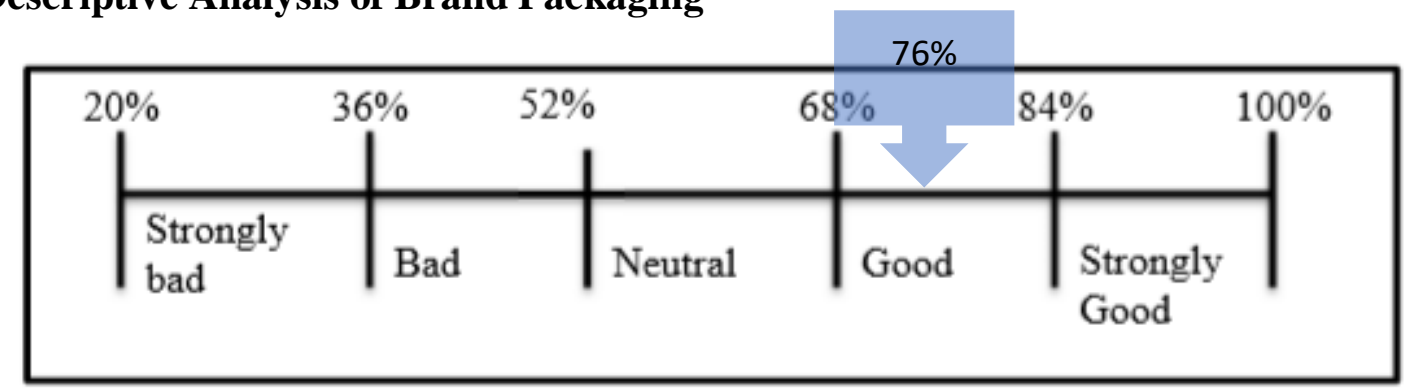

Figure 4.6 Continuum Line Brand Packaging

Source: Data that has been Processed, 2019

Based on the figure above brand packaging is in "good" category with percentage value $76 \%$ on continuum line. Therefore, we can assume that respondent perception to brand packaging is good. Brand Packaging has the value tcount (2.740) > ttable (1.984) and the level of significance 0.011 $<0.05$, it can be concluded that partially there is a significant effect of Brand Packaging on Purchase Intention.

\section{3) Descriptive Analysis of Brand Trust}

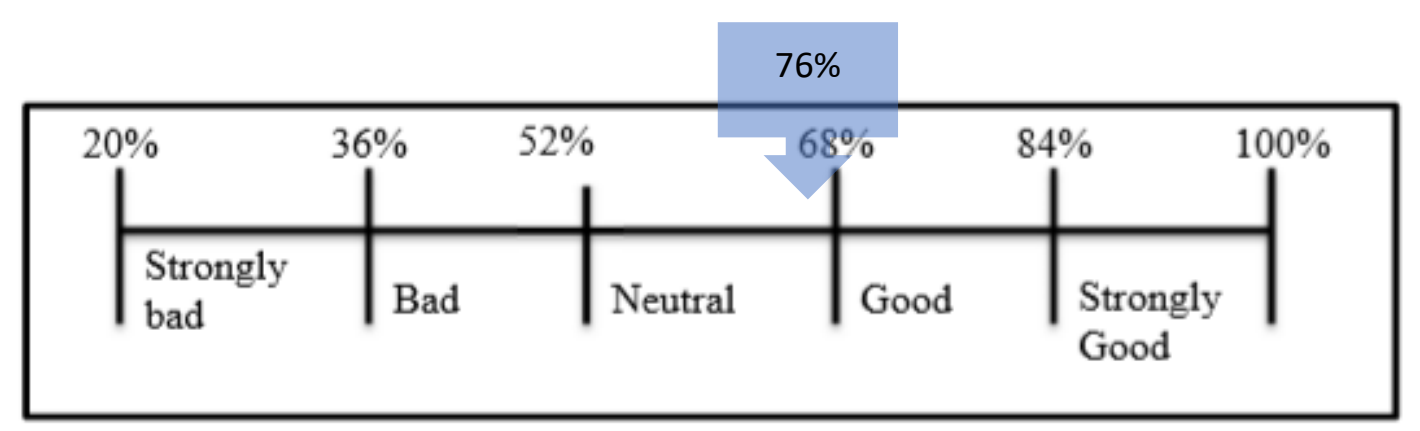

Figure 4.7 Continuum Line Brand Trust

Source: Data that has been Processed, 2019

Based on the figure above brand trust is in "good" category with percentage value $76 \%$ on continuum line. Therefore, we can assume that respondent perception to perceived value is good. Brand Trust has the value tcount (2.490) > table (1.984) and the level of significance $0.014<0.05$, it can be concluded that partially there is a significant effect of Brand Trust on Purchase Intention. 
4) Descriptive Analysis of Purchase Intention

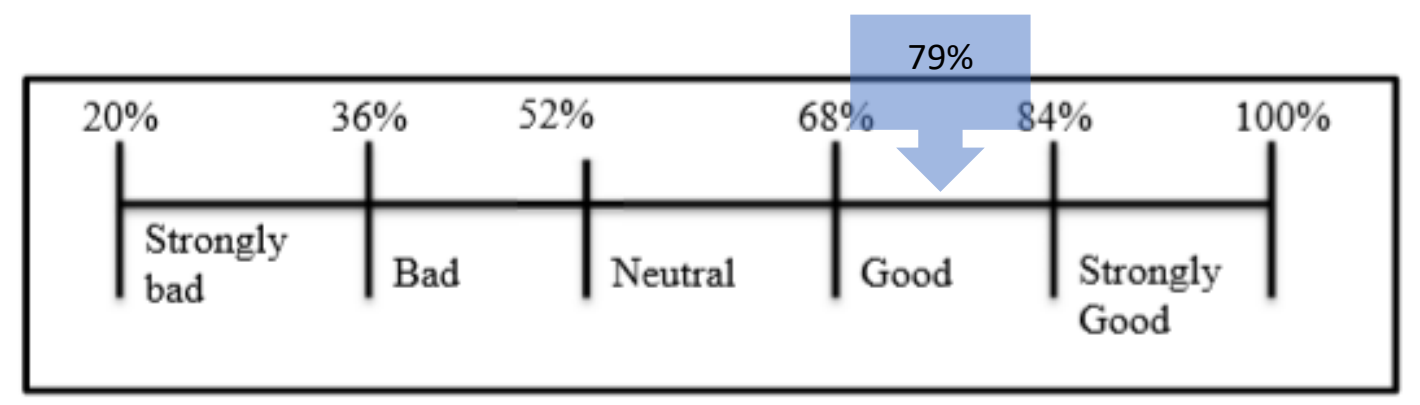

\section{Figure 4.8 Continuum Line Purchase Intention}

Source: Data that has been Processed, 2019

Based on the figure above Perceived value is in "good" category with percentage value $79 \%$ on continuum line. Therefore, we can assume that respondent perception to perceived value is good.

\section{5) Moderating Effect from Gender}

In order to test the last hypothesis $\mathrm{H} 4 \mathrm{H} 5 \mathrm{H6}$, each path was examined separately. The results indicate no significant effect of gender in this study. Because P-value $>0.05$.

Table 4.8 Moderating Effect

\begin{tabular}{|l|l|}
\hline Variable & Indicator (P-value) \\
\hline X1 to Y Moderating by Gender & 0.959 \\
\hline X2 to Y Moderating by Gender & 0.232 \\
\hline X3 to Y Moderating by Gender & 0.344 \\
\hline
\end{tabular}

\section{CONCLUSIONS AND SUGGESTIONS}

\subsection{CONCLUSIONS}

Based on the results, overall factor of purchase intention categorized as good. Perceived value is in "good" category with percentage value $79 \%$, brand packaging is in "good" category with percentage value $76 \%$, and brand trust is in "good" category with percentage value $76 \%$. Shopee already build a good perceived value, brand packaging and brand trust from the customer. For gender differences its show that from total respondent show that dominance with female respondent, we can conclude many females has more interest with online shopping, but this is not affecting their purchase intention. For the result, purchase intention between male and female is same, and no significance difference. 


\subsection{SUGGESTIONS}

\subsubsection{SUGGESTIONS FOR THE COMPANY}

Our study helps managers who work in the marketplace. Managers should build perceived value, brand packaging and trust to create a platform for higher purchase intention. Also, this study also can be valuable for new companies who want to enter market.

For Shopee, or another marketplace which running this business, it is important to interact people and influencing them to have an intention of purchase, and there are no differences intention between male and female, so its better to create a program that universal for both male and female, because they have a same intention. The company also may be focusing to increase the number of user or customer not based on the gender.

\subsubsection{SUGGESTIONS FOR THE FURTHER RESEARCH}

In future studies, it is recommended to collect data directly to the Shopee customers and put a larger area for respondent so the result may be more accurate. And the next researcher also may add another factor that can influences purchase intention of shopee marketplace. 


\section{REFERENCES}

Adiwidjaja Adrian Junio dan Zeplin Jiwa Husada Tarigan (2017) Pengaruh Brand Image dan Brand Trust Terhadap Keputusan Pembelian Sepatu Converse. AGORA Vol. 5, No: 3

Agariya, Kumar Arun, Ankur Johari, Hitesh K Sharma, Udit N S Chandraul, Deepali Singh. (2012). The Role of Packaging in Brand Communication. International Journal of Scientific \& Engineering Research, Vol.3. ISSN 2229-5518.

Alhidari, A. M., \& Almeshal, S. A. (2017). Determinants of Purchase Intention in Saudi Arabia: A Moderating Role of Gender.British Journal of Economics, Management \& Trade. 17(2), 110.

Anwar Sanusi, (2011), Metode Penelitian Bisnis.Jakarta: Salemba Empat,

Asshidin Nor Hazlin, Nurazariah Abidin, Hafizzah Bashira Borhan (2016). Perceived quality and emotional value that influence consumer's purchase intention towards American and local products. Procedia Economics and Finance 35 (2016) 639 - 643

Bilson, Simamora. (2001). Memenangkan Pasar dengan Pemasaran Efektif danProfitabel, Edisi Pertama, Jakarta: PT. Gramedia Pustaka Utama

Chaffey, Dave. (2009). E-Business and E-Commerce Management, $4^{\text {th }}$ edition. England: Pearson.

Christine R. Pardede, S.L.H.V Joyce Lapian, Merinda. (2018) The Influence of Perceived Value and Trust on Repurchase Intention in Shopee Online Shopping. Vol 6, No 1. Jurnal EMBA: Jurnal Riset Ekonomi, Mnanajemen, Bisnis dan Akuntasi.

Ermaningtiastuti Clara. (2019, July 10) Perkuat Pasar Pria, Shopee Kampanye Lagi Men Sale. Retrieved August 5 2019, from: https://marketeers.com/perkuat-pasar-pria-shopee-kampanyelagi-men-sale/

Eryadi Heru Triatmaja, Eka Yuliana, ST., MS (2016) The Influence of Perceived Value and Social Influence to Purchase Intention Smartphone $4 G$ in Customer of Bandung Electronic Center. e-Proceeding of Management: Vol.3, No.1 April 2016 | Page 86

Fahruddin Fahmi Agus, Achmad Fauzi, Edy Yulianto (2015) Pengaruh Atribut Produk Terhadap Keputusan Pembelian. Jurnal Administrasi Bisnis (JAB)|Vol. 28 No. 1 November 2015

Fauzia Mutia, Bambang Priyo. (2019, April 4 $\left.{ }^{\text {th }}\right)$ Markplus survey Shopee Jadi "Top of Mind" Belanja Online bagi Perempuan Indonesia. Retrieved August 5 2019, from: https://money.kompas.com/read/2019/04/05/094200426/shopee-jadi-top-of-mind-belanjaonline-bagi-perempuan-indonesia

Ghozali, Imam. 2013. Aplikasi Analisis Multivariate dengan Program SPSS. Edisi Ketujuh. Semarang: Badan Penerbit Universitas Diponegoro.

Hair, Jr Joseph and friends. (2017) A Primer on Partial Least Squares Structural Equation Modeling (PLS-SEM) Second Edition. United States of America. SAGE Publications. 
Jauhari Tantowi and friends, (2019) The Impact of Website Quality on Consumer satisfaction and Purchase Intention, Jurnal Administrasi Bisnis (JAB)|Vol. 67No.1Februari2019

Jinhee Jun (2012) Gender Identity, Leisure Identity, and Leisure Participation. Retrieved October 20 2019 From: https://www.researchgate.net/publication/264052187 Gender Identity Leisure Identity and Lei sure Participation

Kotler, Philip. \& Gary Armstrong. (2012). Principle Of Marketing, 14 ${ }^{\text {th }}$ Edition. Pearson

Kristie Lorette (2019). Role of Packaging in Market Development. Retrieved October 20 2019, from: https://smallbusiness.chron.com/role-packaging-market-development-1498.html

Marianne R. Klimchuk, Sandra A. Krasovec. 2012. Packaging Design: Successful Product Branding From Concept to Shelf: New Jersey: John Wiley \& Sons, Inc.

Mirabi Dr. Vahidreza, Hamid Akbariyeh, Hamid Tahmasebifard (2015) A Study of Factors Affecting on Customers Purchase Intention Case Study: The Agencies of Bono Brand Tile in Tehran Dr. Vahidreza Mirabi. Vol. 2 Issue 1, January 2015. Journal of Multidisciplinary Engineering Science and Technology (JMEST).

M. Sangadji, \& Sopiah (2010), Metodologi Penelitian. Yogyakarta: ANDI

Oxford Dictionaries (2019). Definition of 'Trust'. Retrieved October 202019 from: https://www.oxfordlearnersdictionaries.com/definition/english/trust 1?q=trust+

Perju-Mitran Alexandra, Andreea Elisabeta (2015). Gender Differences in Modeling the Influence of Online Marketing Communication on Behavioral Intentions. Procedia Economics and Finance 27:567-573 · November

Raji, Mohd Nazri Abdul. Artinah Zaina (2016) The effect of customer perceived value on customer satisfaction: A case study of Malay upscale restaurants. Malaysian Journal of Society and Space 12 issue $3(58-68)$

Rita, SE., M.Si (2018, April 2 ${ }^{\text {nd }}$ ) Brand Trust. International Marketing. Retrieved October 202019 , from: http://bbs.binus.ac.id/international-marketing/2018/04/brand-trust/

Sanchez-Franco, M. J., Ramos, A. F. V., \& Velicia, F. A. M. (2009). The moderating effect of gender on relationship quality and loyalty toward Internet service providers. Information \& Management, 46(3)

Siregar. (2013). Metode Penelitian Kuantitatif. Jakarta: Prenada Media Group.

Shahnaz Nanda Bella Fidanty, Wahyono. (2016) Faktor yang Mempengaruhi Minat Beli Konsumen di Toko Online. Management Analysis Journal. Retrieved October 202019 from http://maj.unnes.ac.id

Shopee company profile cited from: www.shopee.co.id [ August 2019] 
Sohaib, Osama, Kyeong Kang, Mohammad Nurunnabi, (2018) Gender-Based iTrust in E-Commerce: The Moderating Role of Cognitive Innovativeness. Retrieved October 202019 from: https://doi.org/10.3390/su11010175

Sugiyono. (2011). Metode Penelitian Kuantitatif, Kualitatif, R\&D. Bandung: Alfabeta.

Sugiyono. (2012). Metode Penelitian Kuantitatif Kualitatif dan $R \&$ D. Bandung: Alfabeta

Sugiyono. (2013). Metode Penelitian Kombinasi. Bandung: Alfabeta

Sugiyono. (2014). Metode Penelitian Kuantitatif, Kualitatif, dan Kombinasi (Mixed Methods). Bandung: Alfabeta

Widyanto Hanif Adinugroho, Tubagus Achmad Rachmad Saleh (2018). The Influence Of Customers' Perception And Attitudes Toward Customer Purchase Intention At Gramedia Lembuswana, $\begin{array}{lllll}\text { Samarinda. } & \text { Retrieved } & \text { October } & 20 & 2019\end{array}$ https://www.researchgate.net/publication/334281423 The Influence Of Customers' Perception And Attitudes Toward Customer Purchase Intention At Gramedia Lembuswana Samarinda 